\title{
Strengthening Digital Literacy to Develop Technology Wise Attitude Through Civic Education
}

\author{
Anisah Dwi Indah Sari ${ }^{1, *}$, Karim Suryadi ${ }^{2}$ \\ ${ }^{1,2}$ Universitas Pendidikan Indonesia, Bandung, Indonesia \\ ${ }^{*}$ Corresponding author.Email: anisahdwiindahsari@upi.edu
}

\begin{abstract}
This study aims to decide the strengthening of digital literacy in developing technology-wise attitudes through Civics. In the rapid development of technology, it requires people to understand the rules that govern the order in technology, such as social media. The technology literate generation must have a critical, creative, communicative mindset that is supported by information, media and technological capabilities supported by digital literacy skills. To support an attitude that has good values in technology, Civics as value-based education has an important role in forming digital citizens who have responsibility, wisdom, logic and ethics. Focused on the formation of identity to be able to understand and make the rights and obligations of being a smart and good citizen by Pancasila and the 1945 Constitution. With Civics, digital literacy is cultivated and developed which can increase knowledge, skills, and awareness in using technology and its creation. citizens who have digital literacy skills to seek, sort and manage information obtained effectively.
\end{abstract}

Keywords: Civic Education, Digital Literacy, Technology Wise Attitude.

\section{INTRODUCTION}

The progress of science and technology gives its own impression on the spaces of human life. One of them, technology influences on changes in the order of communication between one individual and another, information sharing and other forms of communication. Conventional print communication media such as newspapers have begun to slowly change into the realm of new technology, namely digital media in the form of social media, online news portals and other forms of communication technology. The emergence of social media in the realm of human life provides positive and negative feedback. Various social media such as Facebook, Twitter, Instagram, and other online news portals are the people's choice in communicating and sharing information with each other. In communicating, of course there is interaction, social media and access to other communication media must pay attention to an ethics or language order that is good and right and what is shared is in accordance with true and correct facts and data in accordance with the central characteristics of human nature which always considers behavior before communicating [1]. The community, especially students and other young generations, must be equipped with understanding and reinforcement to develop how to behave properly and politely when using a technology. Rapid changes must be accompanied by the knowledge and skills imparted to the younger generation in particular. Where in the era of revolution 4.0 in the 21 st century, all orders of life use technology. Capability that is supported by knowledge, understanding and strengthening in technology is not easy, considering the rapid changes in globalization require all institutions involved to step in to face this rapid challenge [2]. Education is growing rapidly in line with advances in information and communication technology, making educators have to adapt as quickly as possible to these advances. The presence of technology provides a mindset and perspective that becomes more practical and fast when compared to the past which only relied on information obtained manually such as going to the library, this time information can be obtained only with a tool called a smartphone. A search engine called "google" also dominates students and the public to obtain information from the outside world. This also applies in the world of education which makes ways of thinking and getting information super fast in supporting the learning process [3]. However, on the other hand, can students understand the meaning of the presence of this technology and the positive benefits for themselves and others?

A study conducted by Pritanova stated that a lack of understanding of digital literacy will lead to poor quality of the younger generation in this case it has a 
psychological effect that produces impacts such as insulting others, envy, and other bad attitudes, where this also applies when someone accesses the internet. a technology, this bad impact is also carried over to life in cyberspace [4]. The Education Sector through civic education as education that contains the inculcation of character and moral values provides a strong contribution to the younger generation to respond wisely to changes and attitudes that are in accordance with the values that exist in society and are able to balance with the progress of the world. Civic education as education that instills character and moral values also optimizes its role in providing an understanding of digital citizenship to the younger generation. Optimizing citizenship education in forming good digital citizenship by providing knowledge and skills on the use of digital communication technology, providing an understanding of law, ethics, and literacy in the use of digital communication technology, providing an understanding of physical and psychological health and security and security issues user data. This is done by civic education through the vision and mission of participating in the progress of the nation's life and character and moral development in the younger generation [5]. One of the countries that enjoys technological change, Indonesia with internet users reaching 196,714 million users out of 266,911 million Indonesian population with a growth of $8.9 \%(25,537$ million users) according to APJII data for internet user penetration 2019-2020 (Q2) [6]. With the number of users aged 13 years and over amounting to 210.3 million (77\%), 18 years and over 187.1 million (69\%) and aged $16-64$ years amounting to 179.7 million (66\%) users. Based on the data, there are four platforms that are often accessed, the dominant type of platform accessed is Youtube at $88 \%$, followed by the Whatsapp platform at $84 \%$, the third Facebook at $82 \%$ and the fourth Instagram at $79 \%$ [7]. According to the results of the Kominfo survey in 2020, the reasons people often use or access the internet are communicating via short messages (Whatsapp, Line, Telegram and others) with a percentage of $34.3 \%$, searching for information or browsing the internet by $12.9 \%$ and using social media. (Facebook, Instragram, Twitter and others) by $16.2 \%$.

With the amount of data on internet users in Indonesia, the strengthening of digital literacy is provided through civic education and is packaged with materials and learning that aims to promote knowledge, skills and character following the purpose of strengthening digital literacy for students. Digital literacy as part of the nine elements of digital citizenship is very important to be given through citizenship education because citizenship education can package and provide understanding for students to develop wise attitudes in technology supported by materials that promote the knowledge, skills, and character of students who are following digital ethics, understanding the laws of using technology, health and technology security, and of course the beginning of it all, namely strengthening and understanding digital literacy so that they can face the order of globalization through civic education.

\section{LITERATURE REVIEW}

\subsection{Digital Literacy}

Seeing the phenomenon of using technology media for communication. This is certainly a serious problem, considering the number of users in Indonesia in particular is not small. Users of technology media in Indonesia are also of various ages, one of the media trends used is the use of Facebook media, amounting to 71.6 million or $54 \%$ of users in Indonesia. Of course, that number is not small, considering that the high number of users is certainly accompanied by good and bad impacts for users of the technology. There are so many illegal actions involving the use of technology, such as online gambling, spreading fake news (Hoax), defamation on certain sites or media, online fraud, spreading adult sites (pornography) and other illegal acts. This happens due to lack of awareness and lack of understanding of digital literacy for users. The use of technology that does not follow the rules of law, ethics, and security has resulted in more and more cases involving users of digital (communication) technology. The ability to accurately use digital information and obtain information for academic, work and daily life needs. Able to use and understand the use of technology, obtain and analyze various information presented on accessed digital media portals [8]. In Gilster's textbook, states that digital literacy must be a very important skill to have and improve because all sectors depend on technology, information, and global communications that have a wide network. In this case, a very important skill in the form of digital literacy intelligence, emphasizing the need for a critique of thinking patterns and being able to identify information obtained from various sources so that the information obtained can be useful [9].

The application of digital literacy is not only for the purpose of the effects of advances in communication technology. However, the need for digital literacy is used for many purposes, where the need for user understanding of democracy, knowing the importance of cultural and civic participation, and how the development of an increasingly widespread culture has made the younger generation access digital media a lot [10]. On the other hand, Alkalai argues that digital literacy does not only use software or uses digital technology devices, but rather on how users can use these devices optimally where they are equipped with cognitive, sociological, motor, and emotional abilities or skills so that the user can use the device. used can be used properly and correctly, where digital literacy also includes how to build understanding knowledge of non-linear navigation 
and how to evaluate the quality of information presented and be able to understand wisely the rules that exist in the world of digital technology [11]. In fact, in the life of every individual requires a technology to communicate. The use of information technology such as social media shows that a country needs modernization and discussions with the government, researchers, and technical training so that good outputs are produced in these developments [12]. The use of the internet which is dominated by the middle class causes a phenomenon that the rapid development of digital media and the internet makes all of us have the same attitude as quickly to realize that we are able to manage, receive, and provide information obtained from digital media and the internet. so the need for strengthening in using digital media and the internet [13].

\subsection{Strengthening Digital Literacy Through Civic Education in Developing Technology Wise Attitudes}

In maximizing an advance in technology, information and communication. The government through various institutions related to this matter to participate in advancing, maximizing, and providing teaching to the younger generation in particular, so that they become the younger generation who will determine the progress of a nation in the future. Therefore, we need an education that not only teaches about arithmetic, but more than that, an education that teaches values, morals, character which will later produce a good attitude for the individual. In the scope of education, a school provides education programs where education is given without discrimination, regardless of background, whether students are normal or not, both physically and mentally [14]. Because, education matters for all citizens and is regulated in article 31 of the 1945 constitution. In today's digital era, obstacles and opportunities are also present in Indonesia. These impacts are present in every daily life [15]. A study conducted by Kerr, Rynearson in 2006 found results where the level of skills acquired by students is higher in operating various software and hardware on computers will have a positive effect on the level of success of students in learning [16]. The younger generation in particular, is required to have the skills, intelligence and a wise attitude in the face of globalization. The young generation must be equipped with various intelligences so as to produce a young generation that is ready for global challenges. To deal with this, a learning intelligence is needed that includes various dimensions, namely, the younger generation who are culturally intelligent, politically intelligent, economically intelligent, and of course technologically intelligent [17]. These five dimensions must be owned by the younger generation to be ready to face global challenges.

The purpose of this dimension is in line with the objectives of the scope of Citizenship Education, where civic education does not only look at politics, but also looks at other social sciences, because civics education is an interdisciplinary science with other social sciences [18]. Citizenship Education in its position in the era of globalization has a contribution in this case a teacher must have openness to information and technology, marked by the birth of digital citizenship. Digital citizenship develops and creates a community of technology users to actively evaluate their smart and productive use of technology. Teachers, as at this point, must be able to make the best use of information technology for the benefit of learning as well as provide an understanding of the dangers and benefits of technology itself to students in facing the global world order by emphasizing self-confidence, and remaining steadfast in national identity and being active, independent fiber [19]. Citizenship education also emphasizes the importance of the younger generation to have 21 st century skills. In civic education learning in the current digital era, it can be expected and needed to develop a skill that can help students develop a literacy [20]. Trilling et al, mentions the skills in question, namely learning and innovation skills, namely being able to think critically, communication and creativity, and being able to work together. Creativity and innovation in information technology media and technology skills, namely, media literacy, information literacy, technological literacy, information and communication, and life and career skills, namely, flexibility and being able to adapt, direct themselves towards social and cultural productivity and have leadership and responsibility [21].

One way of civic education is to develop a wise attitude that is in accordance with the goals of smart and good citizens in technology for students. Civic Education teachers in providing strengthening digital literacy are by inserting all Basic Competencies in civic education subjects, especially at the elementary, junior high and high school levels [22]. The learning model in the form of VCT in civics education can improve the civic character of students [23]. One of the wise attitudes in technology is the existence of a responsible character. In the study of VCT in civics education, research conducted by Dahliar found that the learning process with VCT can grow and increase the responsibility of students in social awareness of students [24]. In addition, civic education forms the younger generation as smart and good citizens, namely having three components of knowledge, skills, and dispositions [25]. In addition, in civic education, there is also blended learning which is a learning system that combines face-to-face learning with online learning. In this learning, a teacher is required to carry out the learning process with two learning systems, face-to-face and online that utilize technology. Based learning is considered capable of making students improve their understanding and quality in understanding digital literacy which is very much needed in the face of the 
revolution era. [26]. Transformation in the character of students needs to be carried out because it is pursued as preparation for the 4.0 revolution and 21 st century education. One way is by developing learning materials and digital literacy learning methods at school and outside of school. It is hoped that with this learning activity, the character of students remains in line with the vision and mission, responsibility, social sensitivity, and logical ability of students to produce mature characters who are ready to face global developments and are able to compete internationally [27].

In conclusion, civic education forms the younger generation or students in the realm of digital citizenship, namely digital literacy as one of the preparations for the younger generation in facing the challenges of globalization. Where so that students or the younger generation become smart and good citizens who have the characteristics of 21 st century citizens [28]. The central values that become the reference in character are contained and sourced from the values of Pancasila which are priorities in the development of character values, namely nationalism, religion, independence, cooperation and integrity. These values must develop with each other in interacting together so that they are formed dynamically that are useful for personal life or oneself [29]. On the other hand, there is a view on the addition of training on information skills in the use of the internet, it is believed that if the internet is used to obtain specific information and information, then additional skills in this area are needed. It is important to provide training at the education level from elementary school to university [30].

\section{CONCLUSION}

Looking at the history of the Indonesian nation, the values contained in Pancasila are intended as guidelines in everyday life. The values of courtesy, decency, law and other rules are contained in every precept of Pancasila. One of the values contained in the precepts of Pancasila which is currently reflected in the civilization of modern life in the digital era, namely the value of tolerance, social solidarity and responsibility for the actions taken. This is reflected in life, the value of tolerance is believed to be one of the foundations in life, with the use of technology, the value of tolerance is needed as a reference in respecting others, such as personal rights, as well as other rights owned by others, in social media, the value of tolerance. used to respect the opinions of others in cyberspace, to appreciate the cultural values that each individual brings in socializing, including socializing on social media. Pancasila education, citizenship education, and character education must be contained and taught to every student from elementary to university levels. The basic level is given about 70 percent and the intermediate level is about 60 percent. Hoping that it will have a significant impact on students' understanding in applying the good values taught in civics education as a guide for the nation and state.

Civic education as one of the subjects that have the task of shaping citizens to become smart and good citizens not only teaches the values, norms, and rules in the state, more than that, civic education plays an important role in shaping citizens to be ready to face global challenges. One of the goals is to prepare citizens who are able to condition themselves in the changing times but still hold fast to the values and character of the Indonesian nation. Civic education contributes to the formation of digital citizenship through one of its elements, namely digital literacy. Where digital literacy is expected to be able to shape and develop the character, attitude and personality of citizens who obey the rules, ethics, law, security and health in technology as one of the three components of citizens who are smart and good citizens, namely knowing, then, skills, it is hoped that digital literacy provided through civic education can be optimized so that citizen skills are formed who can filter news or content published on online news portals or social media. Character, it is hoped that the character of citizens who are developed in understanding and strengthening digital literacy through civic education can make the character of citizens who are responsible for every upload, download, and dissemination of content posted on sites or social media and actions related to digital technology be expected. others on the internet and have ethics and understand the laws that bind to every activity in cyberspace.

\section{REFERENCES}

[1] Irhamdi. M, Menghadirkan Etika Komunikasi di Media Sosial, Jurnal Komunike, Volume X, No.2, pp.146, Desember 2018. https://doi.org/10.20414/jurkom.v10i2.676.Pp.146

[2] Saleh. M, Kolamalasari, Sapriya, and Iim, Civic Education Learning in the 21st Century SkillsBased Digital Era, The 3rd International Conference on Elementary Education (ICEE 2020), Volume 3, pp.279, 21 November 2020. ISBN 978623-6988-28-2

[3] F. Faris, Aim Abdulkarim, Kokom Komalasari, Teacher Competency in Civic Education Learning to Encounter Industrial Revolution 4.0 (Case Studi at Sekolah Menengah Pertama 2 Bandung, Journal of International Conference Proceedings, Vol.3, No.1, 2020.2 DOI: https://doi.org/10.32535/jicp.v2i4.785

[4] Rahmayanti. E, Penguatan Literasi Digital untuk Membentuk Karakter Kewarganegaraan Digital melalui Pendidikan Kewarganegaraan, Prosiding 
Seminar Kewarganegaraan Universitas Ahmad Dahlan Yogyakarta, pp.80, 29 Juni 2020. ISSN 2715-467X

[5] Komalasari. K, Diana Noor. A, Civic Education for Development of Digital Citizenship in the Era of Industrial Revolution 4.0, Advances in Social Science, Education and Humanities Research 2nd Annual Civic Education Conference (ACEC), Volume 418, pp.153. 2019

[6] B.D. Jarot. Jumlah Pengguna Internet di Indonesia Capai 196,7 Juta. Available at https://databoks.katadata.co.id/datapublish/2020 /11/11/jumlah-pengguna-internet-di-indonesiacapai-1967-juta Publish in 2020

[7] Riyanto. A. D. Hootsuite (We are Social): Indonesian Digital Report 2020. Available https://andi.link/hootsuite-we-are-socialindonesian-digital-report-2020/ . Publish in 2020

[8] Riel. J, Christian, S., \& Hinson, B.Charting, Digital Literacy: A framework for Information Technology and Digital Skills Education in The Community College, Presentado en Innovations, pp.3, 2012. DOI: 10.2139 / ssrn.2781161

[9] Riel. J., Christian, S., \& Hinson, B.Charting, Digital Literacy: A framework for Information Technology and Digital Skills Education in The Community College. Presentado en Innovations, pp.4, 2012. DOI: 10.2139 / ssrn.2781161

[10] Koltay. T, The Media and The Literacies: Media Literacy, Information Literacy, Digital Literacy, Media, Culture, \& Society, Volume 33, No.2, pp.211-22. 2011

[11] Alkalai \& Eshet,Y. Digital literacy: A Conceptual Framework for Survival Skills in The Digital Era. $J$ of Educational Multimedia and Hypermedia ,Volume 13, No.1, pp.93-106. 2004

[12] A. Trisiana, Digital Literation Models for Character Education Globalization Era, Humanities and Social Sciences Review, Vol, 8, No.1, pp.522, eISSN: 2395-6518, , 2020. https://doi.org/10.18510/hssr.2020.8164

[13] Endang Danial, Iim Siti Masyitoh, and Sri Wahyuni Tanshzil, Education for All Citizens. Advances in Social Science, Education and Humanities Research 2nd Annual Civic Education Conference (ACEC), Volume 418, pp.502, 2019

[14] Indriyani. D, Modal di Era Disrupsi. Prosiding Seminar Nasional Kewarganegaraan Universitas Ahmad Dahlan Yogyakarta, pp.44, 29 Juni 2020. ISSN 2715-467X
[15] Rahmayanti. E, Penguatan Literasi Digital untuk Membentuk Karakter Kewarganegaraan Digital melalui Pendidikan Kewarganegaraan, Prosiding Seminar Kewarganegaraan Universitas Ahmad Dahlan Yogyakarta, pp.83, 29 Juni 2020. ISSN 2715-467X

[16] Yustika, G. Perwira \& Sri Iswati, Digital Loteracy in Formal Online Education: A Short Review, Dinamika Pendidikan, Vol.15, No.1, pp.70, 2020. E-ISSN: 2502-5074, P-ISSN: 1907-3720. DOI: 10.15294/dp.v15il.23779

[17] Rahmayanti. E, Penguatan Literasi Digital untuk Membentuk Karakter Kewarganegaraan Digital melalui Pendidikan Kewarganegaraan, Prosiding Seminar Kewarganegaraan Universitas Ahmad Dahlan Yogyakarta, pp.83, 29 Juni 2020. ISSN 2715-467X

[18] Muhamad. S, Kokom, Sapriya, and Iim Siti Masyitoh, Civic Education Learning in the 21st Century Skills-Based Digital Era, The 3rd International Conference on Elementary Education (ICEE), Volume 3, pp.282, 21 November 2020. ISBN 978-623-6988-28-2

[19] F. Faris, Aim Abdulkarim, Kokom Komalasari, Teacher Competency in Civic Education Learning to Encounter Industrial Revolution 4.0 (Case Studi at Sekolah Menengah Pertama 2 Bandung, Journal of International Conference Proceedings, Vol.3, No.1, pp.108, 2020. DOI: https://doi.org/10.32535/jicp.v2i4.785

[20] Muhamad. S, Kokom, Sapriya, and Iim Siti Masyitoh, Civic Education Learning in the 21st Century Skills-Based Digital Era, The 3rd International Conference on Elementary Education (ICEE), Volume 3, pp.282, 21 November 2020. ISBN 978-623-6988-28-2

[21] Benziria, Pengembangan Literasi Digital pada Warga Negara Muda dalam Pembelajaran PPKn melalui Model VCT, Jurnal Pendidikan Ilmu-Ilmu Sosial, Volume 10, No.1, pp.17, 2018

[22] Nuryanta dan Suyato, The Impact of The Using of Value Clarification Technique (VCT) Towards Civic Disposition Building in Civics Subject for Grade X of Senior High School 1 Piyungan, Jurnal Pendidikan Kewarganegaraan dan Hukum, Volume 1, No.13, 2016

[23] Lakstian. V, The Contributions of Literacy skills to National Development, Journal Leksema, Volume 1, pp.11-118, 2016

[24] Dahliar. The Implementation of VCT (Value Clarification Technique) Modelin Improving 
Students Responsibility Character on Environmentin Indonesia (A Case Study in State Senior High Schools in Solok Regency), Sumatra, Journal of Disaster, Geography and Geography Education, Volume 1, pp.293-297, 2017

[25] Fajar. R.P.A.L, Dinie. A. D, Implemnetasi Pendidikan Kewarganegaraan Generasi Muda sebagai Smart and Good Citizen di Era Disrupsi, Jurnal Pekan, Volume 6, No.1, pp.83, Edisi April 2021. ISSN: $2540-8038$

[26] Indriyani. Dina, Application of Blended Learning in Citizenship Education Learning of Digital Literacy Efforts for Students, Proceeding books: The 2nd International Conference and Innovation Exhibiti on Global Education (ICEGE), Universitas Muhammadiyah Prof. DR. Hamka, pp.184, January 2020. DOI: https://doi.org/10.22236/ie.v1i1.108

[27] Dewi, Emi \& A. Aminullah Alam, Transformation Model for Character Education of Students, Cypriot Journal of Educational Sciences, Vol.15, No.5, pp.1228, 2020 . DOI: https://doi.org/10.18844/cjes.v15i5.5155

[28] Rahmayanti. E, Penguatan Literasi Digital untuk Membentuk Karakter Kewarganegaraan Digital melalui Pendidikan Kewarganegaraan, Prosiding Seminar Kewarganegaraan Universitas Ahmad Dahlan Yogyakarta, pp.85, 29 Juni 2020. ISSN 2715-467X

[29] C. Mahfud, Moh.Saifulloh, Niken, Dyah, Wayan, Enie. H \& Charis, Digital The Value of Regilious Character, Pancasila and Citizenship Education Through Youtube, Modeling, Vol.8, No.2, pp.174. September 2021

[30] Yustika, G. Perwira \& Sri Iswati, Digital Loteracy in Formal Online Education: A Short Review, Dinamika Pendidikan, Vol.15, No.1, pp.70, 2020. E-ISSN: 2502-5074, P-ISSN: 1907-3720. DOI: 10.15294/dp.v15il.23779 